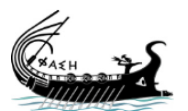

journal.phaselis.org

\title{
Phaselis Kent Limanları ve Sualtı Araştırmalarının Ön Değerlendirmesi
}

\author{
Pre-assessment of the City Harbours and Underwater \\ Explorations of Phaselis
}

Erdoğan ASLAN - Selda BAYBO

open $\bigcirc$ access journals

PHASELIS: Disiplinlerarası Akdeniz Araştırmaları Dergisi'nde bulunan içeriklerin tümü kullanıcılara açık, serbestçe/ücretsiz "açık erişimli" bir dergidir. Kullanıcılar, yayıncıdan ve yazar(lar)dan izin almaksızın, dergideki makaleleri tam metin olarak okuyabilir, indirebilir, dağıtabilir, makalelerin çıktııını alabilir ve kaynak göstererek makalelere bağlantı verebilir.

PHASELIS: Disiplinlerarası Akdeniz Araştırmaları Dergisi uluslararası hakemli elektronik (online) bir dergi olup değerlendirme süreci biten makaleler derginin web sitesinde (journal.phaselis.org) yıl boyunca ilgili sayının içinde (Volume I: Ocak-Aralık 2015) yayımlanır. Aralık ayı sonunda ilgili yıla ait sayı tamamlanır.

Dergide yayımlanan eserlerin sorumluluğu yazarlarına aittir.

Makale Künyesi

E. Aslan - S. Baybo, "Phaselis Kent Limanları ve Sualtı Araştırmalarının Ön Değerlendirmesi”. Phaselis I (2015) 1-17. DOI: 10.18367/Pha.15001

Kabul Tarihi: 15.01.2015 | Online Yayın Tarihi: 12.06.2015

Editörya Phaselis Research Project

www.phaselis.org 


\title{
Phaselis Kent Limanları ve Sualtı Araştırmalarının Ön Değerlendirmesi
}

\author{
Pre-assessment of the City Harbours and Underwater Explorations of Phaselis
}

\author{
Erdoğan ASLAN* Selda BAYBO**
}

\begin{abstract}
Öz: Günümüzde Antalya Ili, Tekirova Illçesi sınırları içinde bulunan ve Pamphylia Körfezi'nin batı sahilinde yer alan Phaselis kenti üç doğal limana ve bir de demirleme alanına sahiptir. Phaselis'in bir liman kenti olduğu, önemli deniz rotaları üzerinde bulunduğu ve bu konumu dolayısıyla denizcilik tarihinde birçok olayda rol aldığı antik kaynaklardan anlaşılmaktadır. Bu nedenle Phaselis ve Teritoryumu Yüzey Araştırmaları kapsamında kent limanlarına yönelik sualtı ve yüzey araştırmaları da yapılmaktadır. Araştırmanın hedefi kent limanlarının yeri, tarihi ve gelişim evrelerinin saptanmasıdır. Buna ek olarak limanların kullanıma yönelik olarak, liman yapılarının-donatılarının işlevlerinin saptanması ve yapım teknolojilerinin anlaşııması da amaçlanmaktadır. 2013-2014 yıllarında yapılan araştırmalarda kentin üç doğal limanı ve bir demirleme alanı olduğu belirlenmiştir. Söz konusu limanların eldeki veriler ışığında Arkaik Dönem’den Geç Antik Dönem'e kadar kullanıldığı ve Phaselis'in dört limanı ile antikçağda ender görülen bir kıyı kenti olma özelliği taşıdığı görülmektedir.
\end{abstract}

Anahtar sözcükler: Phaselis · Liman · Sualtı · Batık · Lykia-Pamphylia

Abstract: The city of Phaselis which is today within the borders of the Tekirova district of Antalya Province and on the west coast of the Gulf of Pamphylia, has three natural harbours and an anchorage area. It is understood from the ancient texts that Phaselis was a coastal town located on important sea routes and played a role in many incidents of maritime history due to its location. Thus, underwater and surface explorations directed to the city harbours have also been conducted, within the Surface Explorations of Phaselis and its Territorium. The aim of this research was to determine the location, history and developmental stages of the city harbours. In addition, it aimed to determine the functions of the harbour structures related to harbour use and to make clear the construction technologies employed. It was determined during the research periods of 2013-2014 that the city has three natural harbours and an anchorage area. From the current data it is understood that these harbours were used from the Archaic Period through to Late Antiquity and Phaselis was therefore a coastal town with four harbours, a type which is rarely found in antiquity.

Keywords: Phaselis · Harbour · Underwater · Shipwreck · Lycia-Pamphylia

Günümüzde Antalya İli, Tekirova İlçesi sınırları içinde bulunan ve Pamphylia Körfezi'nin batı sahilinde yer alan Phaselis kenti üç doğal limana ve bir de demirleme alanına sahiptir (Fig. 1). Phaselis ve Teritoryumu Yüzey Araştırmalarının bir ayağını da kent limanlarına ve çevresine yönelik sualtı yüzey araştırmaları oluşturmaktadır. Bu çalışmanın amacı kent limanlarının yeri,

* Dr., Selçuk Üniversitesi, Edebiyat Fakültesi, Arkeoloji Bölümü, Sualtı Arkeolojisi Anabilim Dalı, Konya. erdoganaslan@selcuk.edu.tr

** Doktora Öğrencisi, Selçuk Üniversitesi, Sosyal Bilimler Enstitüsü, Sualtı Arkeolojisi Anabilim Dalı, Konya. seldabaybo@hotmail.com 
tarihi ve gelişim evrelerinin saptanmasıdır. Buna ek olarak limanların kullanıma yönelik olarak, liman yapılarının-donatılarının işlevlerinin saptanması ve yapım teknolojilerinin anlaşılması da amaçlanmaktadır. Ayrıca gerek kent limanlarının liman havzalarında gerekse kentin sınırları içinde yer alan diğer denizel alanlarda sualtı araştırmaları yapılmaktadır. Bu suretle elde edilen materyal kültür kalıntıları yolu ile limanların kullanım süreçleri ve ticari fonksiyonların saptanmasına yönelik çalışmalar da gerçekleştirilmektedir. 2013-2014 yılları arasında yürütülmüş olan çalışmalar sonucunda elde edilen ilk bulguların bir ön değerlendirmesi niteliğinde hazırlanan bu çalışmada kent limanlarına yönelik antik kaynaklar ve daha önceki yıllarda yapılan çalışmalar taranmıştır. Illaveten tarafımızca gerçekleştirilen çalışmalara ait gözlemler ve yorumlar söz konusu bu araştırma külliyatıyla birleştirilmek suretiyle ileriki yıllarda yapılacak çalışmalar için bir alt yapı oluşturulması hedeflenmektedir.

Arkaik Dönem'den itibaren Rhodos'un bir koloni kenti statüsünde varlığını sürdüren kentin limanlarına ilişkin doğrudan bir tarif erken dönem kaynaklarında bulunmamaktadır. Bununla birlikte, kentin bir liman kenti olduğu ise birçok kaynakta belirtilmektedir ${ }^{1}$. Öyle ki M.Ö. VI-II.

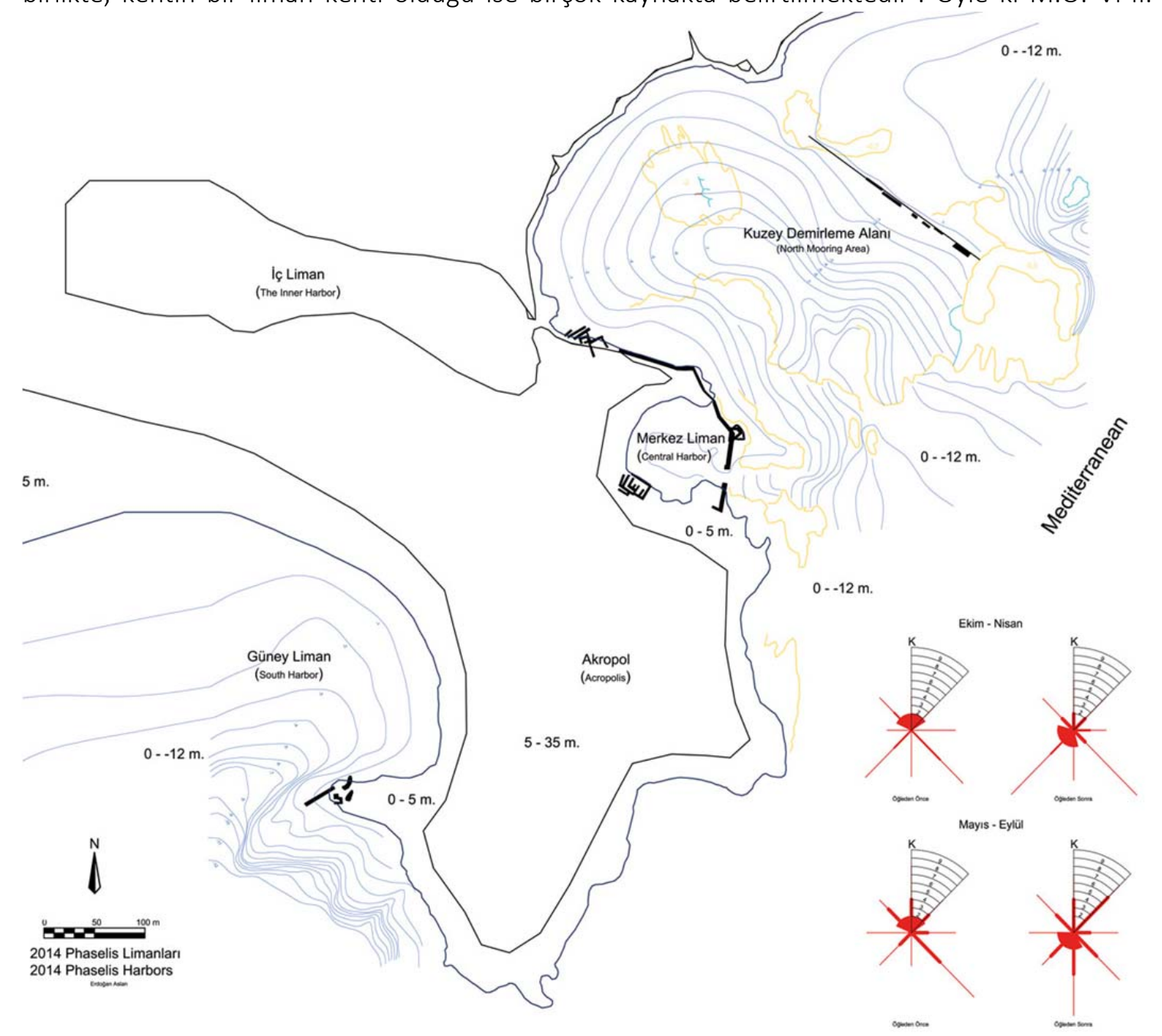

Fig. 1. Phaselis Kent Limanları Genel Planı ve Rüzgâr Frekansı

1 Tüner-Önen 2008, 17 vd. 
yüzyıllar arasında darp edilmiş olan kent sikkelerinde yer alan gemi pruva ve pupaları ${ }^{2}$ vasıtasıyla kentte limanların yanı sıra bir tersanenin de bulunduğu çıkarımı yapılabilmektedir. Limanları ve coğrafi konumu ile bölgesinde önem arz eden kentin Attika-Delos Deniz Birliği'ne (M.Ö. 469411) katılmamasının Kimon tarafından vergi cezasına çarptırılmasına neden olduğu; sonrasında ise kent limanlarının Limyra Beyi Perikle tarafından kuşatıldığı bilinmektedir ${ }^{3}$. M.Ö. V. yüzyılın sonlarında Thukydides, Peloponnesos Savaşı'nın (M.Ö. 431-404) başlarında Atina'nın, Phaselis Phoinike - Atina arasında denize açılan ticaret gemilerinin güvenliğini sağlamak için Phaselis'e 6 gemilik küçük bir filo gönderdiğinden bahsetmektedir ${ }^{4}$. M.Ö. IV. yüzyılda Pseudo-Skylaks'ın Lykia ve Pamphylia limanlarını sıraladığı anlatımında Siderous Limanı ile Idyros Kenti arasında bulunan bir liman kenti olarak tanımladığı Phaselis ${ }^{5}$, Büyük İskender'in Anadolu seferi sırasında yine limanları dolayısıyla önemli bir rol oynamaktadır ${ }^{6}$. İskender sonrası süreçte imzalanan Apameia Antlaşması (M.Ö. 188) ile Phaselis'in bağımsızlığına kavuşmuş olması dolayısıyla kent limanlarının da kendi bölgesinde ayrı bir önem kazandığı öngörülmektedir ${ }^{7}$. Bir liman kenti olan Phaselis kuruluşundan itibaren uygun konumu ve elverişli limanları nedeniyle Ege ve Doğu Akdeniz arasındaki deniz ulaşımının da önemli bir uğrak noktası olmuştur ${ }^{8}$. Öyle ki Atina'dan Mısır'a giden ticaret yolunun; Ege Adaları, Ionia, Rhodos, Knidos, Patara, Andriake, Phaselis, Kelenderis, Kıbrıs, Phoinike rotasını takip ettiği görülmektedir ${ }^{9}$. Livius'un (M.Ö. I - M.S. I. yüzyıl) aktarımlarına göre, Hannibal (M.Ö. 247 - M.Ö. 183) tarafından Suriye'den sevk edilen donanmaya karşı Samos'tan yola çıkan Rhodos'lu Eudamos da, "Phaselis, Lycia-Pamphylia sınırında ve denize doğru çıkan bir burnun üzerinde yer almaktadır. Cilicia'dan Rhodos'a giden gemilerin gördüğü ilk kent olup, denize doğru geniş bir bakışa sahiptir" şeklindeki ifadesiyle kentin bu konumuna vurgu yapmıştır. Zira kendisi de komutasındaki donanmayla birlikte düşmanı Phaselis'te beklemiştir ${ }^{10}$. Attaleia kentinin kuruluşuna kadar (ca. M.Ö. 150) Pamphylia Körfezi'ndeki önemli bir liman kenti olan Phaselis ${ }^{11}$, M.Ö. I. yüzyıla gelindiğinde, bir korsan yuvası haline gelmiştir $^{12}$. Bölgede faaliyet gösteren korsanların lideri Zeniketes, Olympos, Korykos ve Phaselis kentlerinin sığınmaya ve gizlenmeye elverişli limanlarından dolayı bu kentlere ait limanları korsan gemileri için bir üs haline getirmiştir ${ }^{13}$. Roma Dönemi'nde ise Roma'ya tahıl taşıyan devasa İskenderiye gemilerinin de Doğu Akdeniz'den Pamphylia Denizi'ne ve buradan da yine kıyıyı izleyerek Lykia sahil şeridi üzerinden Roma’ya ulaştıkları bilinmektedir. Diğer yandan Mezopotamya ve Suriyeli tüccarların Mısır’a giden ana gemi rotası da Kilikia ve Lykia güzergâhlarından geçmekteydi. Phoinike ve Syria gemileri İskenderiye'ye giderken, Kilikia ve Lykia limanlarına uğrayarak Rhodos'a geçer buradan da İskenderiye'ye yelken açarlardı ${ }^{14}$. Dolayısıyla hem doğudan batıya hem de batıdan doğuya ticaret yapan gemiciler Anadolu'nun güney kıyılarını

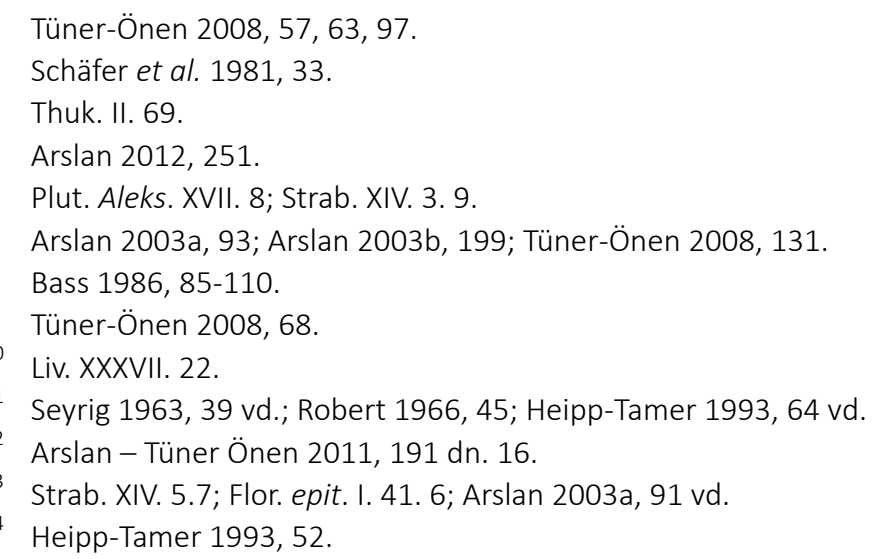


takip ederek burada bulunan limanlara uğramaktaydılar ${ }^{15}$. Dolayısıyla iki büyük ve bir küçük limanı ile Phaselis'in bu rota üzerindeki önemli ve stratejik bir konumda yer aldığı görülmekte$\operatorname{dir}^{16}$.

M.S. III. yüzyıl kaynaklarından Stadiasmus Maris Magni'de ise aynı rota "Sahil boyunca uzanan bu rota Lyrnas Limanı'nda ara istasyon yaptıktan sonra batıya doğru Phaselis'e gelmekte, oradan da Korykos ve adalar üzerinden yoluna devam etmekteydi" ${ }^{17}$ biçiminde tarif edilmektedir. Bu aktarımdan söz konusu güzergâh boyunca seyreden gemiciler için Phaselis limanlarının önemini M.S. III. yüzyılda da koruduğu anlaşıımaktadır.

Phaselis'in liman kenti olduğu ve konumu dolayısıyla da önemli deniz rotaları üzerinde bulunduğu ve bu konumu nedeniyle denizcilik tarihinde birçok olayda rol aldığı antik belgelerden anlaşılmaktadır. Ancak kentin limanlarının fiziki durumuna ve sayısına ilişkin bilgi veren tek kaynak Strabon'un Geographika (M.Ö. I - M.S. I. yüzyıl) adlı eseridir. Strabon, "... bundan sonra, önemli, üç limanlı bir kent olan Phaselis'e ve bir göle gelinir" ${ }^{18}$ şeklindeki aktarımı ile kentin M.Ö. I. - M.S. I. yüzyıllarda üç limanlı bir kent olduğunu belirtmektedir. Dolayısıyla günümüze ulaşan bu üç limanın Strabon'un tarif ettiği biçimini koruduğu ve Phaselis limanlarının son biçimi olduğu anlaşılmaktadır.

Phaselis kent limanlarına ilişkin modern araştırmalar incelendiğinde, 1811-1812 yıllarında F. Beaufort, Phaselis'e ilk ziyareti gerçekleştirmiş ve Strabon'un anlatımına atıf yaparak kentin üç limanı ile bataklığa dönüşmüş gölünden söz etmiştir ${ }^{19}$. Limanların da yer aldığı kent planını çizen Beaufort'a kadar limanlara ilişkin daha önceki dönemlere ait bir çizim de bulunmamaktadır ${ }^{20}$. 1923 yıında yayımlanan antikçağ limanları hakkındaki kitabında Lehmann-Hartleben, Phaselis limanlarına kısaca değinerek Beaufort'a atıf yapması dışında detaylı bir inceleme söz konusu olmamıştır ${ }^{21} .1956$ yılında F. Stark ${ }^{22}$ ve 1968 yılında G. E. Bean ${ }^{23}$ kenti kısa bir süreliğine ziyaret etmişler; ancak bölgeyi ziyaret eden daha önceki birçok araştırmacı gibi ${ }^{24}$ kentin üç limanının olduğu dışında limanlara ilişkin kapsamlı bir bilgi aktarmamışlardır. 1968 yılında Alman Arkeoloji Enstitüsü’nden H. Schläger, Phaselis limanlarını araştırmak amacıyla sualtı araştırmaları gerçekleştirmiştir; ancak 1969 yılında vuku bulan bir dalış kazası nedeniyle hayatını kaybetmesi üzerine onun çalışmalarını 1970 yılında yine aynı enstitüden J. Schäfer, P. Knoblauch ve D. J. Blackman devam ettirmiştir. 1971 yııında kentin birçok yapısının yanında limanlarının da yer aldığı araştırma sonuçları yayınlanmış ve Phaselis limanları konusunda ilk bilimsel çalışma da bu olmuştur ${ }^{25} .1973$ yılında önceki araştırma ekibinde yer alan D. J. Blackman, salt kent limanlarını ele aldığı bir ön rapor ile limanları tekrar ele almıştır ${ }^{26} .1981$ yılındaysa editörlüğünü J. Schäfer'in yaptığı kapsamlı bir çalışma olan Phaselis kitabı yayınlanmış ve kitapta Phaselis limanlarına ilişkin

Heipp-Tamer 1993, 58

Heipp-Tamer 1993, 52,76.

Müller 2010, 427 vd.

Strab. XIV. 3. 9.

Beaufort 2002, 58.

Beaufort 2002, 55.

Lehmann-Hartleben 1923, 20, 276.

Stark 1956, 172 vd.

Bean 1968, 151 vd.

Diğer araştırmacılar için bk. Schäfer et al. 1981, 13 vd.

Schläger - Schäfer 1971, 542 vd.

Blackman 1973, 335 vd. 
bir bölüm de yer almıştır ${ }^{27}$. Bu yayından sonra N. Tüner-Önen'in 2008 yılında tamamlanan doktora tezinin bir bölümünde ele aldığı Phaselis limanları ${ }^{28}$ konusunda günümüze kadar kayda değer başka bir çalışma yapılmamıştır. 2012 yılından itibaren başkanlığını Prof. Dr. Murat Arslan'ın üstlendiği Phaselis Antik Kenti ve Teritoryumu Yüzey Araştırmaları kapsamında konuya tekrar eğilerek gelişen teknoloji ile modern araştırma ve belgeleme yöntemleri kullanılarak Phaselis limanları ve çevresine yönelik sualtı Araştırmaları tekrar başlatılmıştır.

\section{3 - 2014 Phaselis Kent Limanları ve Sualtı Araştırmaları}

Kentin limanları daha önceki araştırmalarda bulunduğu konuma göre Kuzey Limanı, Güney Limanı ve Merkezi Liman olarak adlandırımıştır. Çalışmamızda da Merkezi Liman ve Güney Limanı aynı adla anılmış; ancak daha önce Kuzey Limanı olarak adlandırılan alan Kuzey Demirleme Alanı, göl ya da bataklık olarak anılan alan ise tarafımızca İ̧ Liman olarak anılmıştır.

\section{Kuzey Demirleme Alanı}

Kentin kuzeyinde bulunan ve yaklaşık $350 \times 450 \mathrm{~m}$. ölçülerindeki doğal koy daha önceki çalışmalarda "Kuzey Limanı" olarak isimlendirilmiştir ${ }^{29}$. Söz konusu alan kentin yaklaşık $250 \mathrm{~m}$. kuzeyinde, denize doğru çıkıntı yapan burundan başlayan ve bu burnun yaklaşık $300 \mathrm{~m}$. güneydoğusunda bulunan küçük bir ada oluşumuna kadar uzanan bölgedir. Kentin kuzeyinde bulunan doğal koyun kuzeydoğu bölümünde kıyıdan 30 metre açıkta 100 metre uzunlukta kayalık bir adacık ile yine kıyıdan 300 metre açıkta bulunan 100x80 metre ölçülerindeki ikinci bir alçak kayalık ada bulunmaktadır. İki adacık arasında kalan 200 metre uzunluğunda ve yaklaşık 1,5 metre derinliğindeki sığlık alan moloz taşlarla doldurularak geniş bir platform oluşturulmuş ve bu platformun üzerine de bir adadan diğerine uzanan kuzeybatı-güneydoğu doğrultusunda, yaklaşık 200 metre uzunluğunda ve 4 metre genişliğinde bir duvar örülmüştür (Fig. 1). Bu alandaki örgü duvar yapısı günümüzde tamamen sualtında bulunmaktadır ve büyük oranda tahrip olmuştur. Büyük boyutlu blok ve moloz taş kullanılarak inşa edildiği anlaşılan duvar, gerek Merkezi Liman'ı gerekse duvarın batısında bulunan alanı doğudan gelen dalgalara karşı koruyan bir dalga kıran işlevi görmüş olmalıdır (Fig. 2-3). Dalga kıranın batısında kalan bölgede rıhtım ya da iskele benzeri bir alanın olmaması ve kente nispeten uzak olması nedeniyle doğal koyun bir demirleme alanı olduğu düşünülmektedir. Demirleme alanının en derin yeri 7-8 m. arasındaki derinliğe ulaşmaktadır ve alanda yoğun bir moloz dolgu ve doğal kayadan oluşan sığlıklar olduğu görülmek-

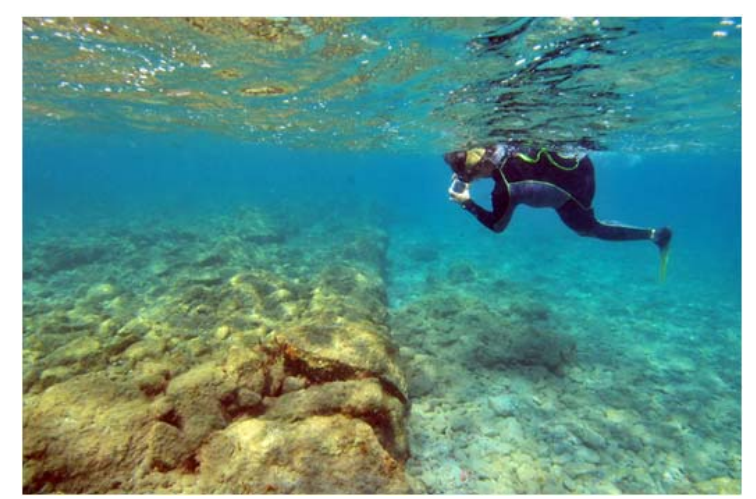

Fig. 2. Kuzey Dalgakıranı

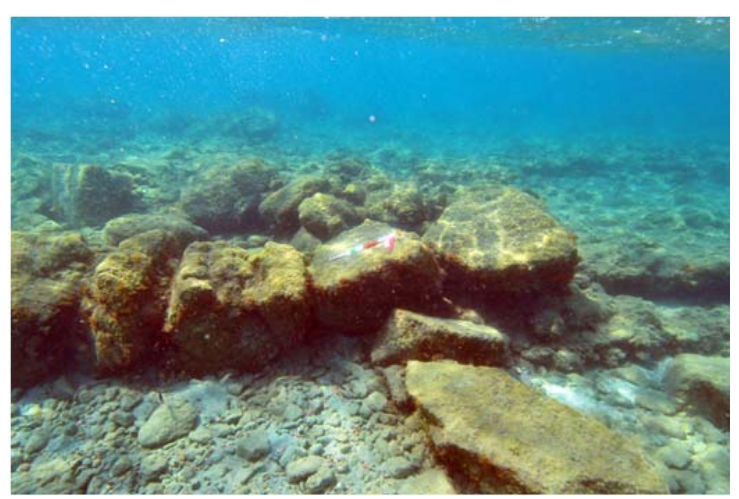

Fig. 3. Kuzey Dalgakıranı Doğudan Görünüş

27 Schäfer et al. 1981, 1.

28 Tüner-Önen 2008, 67-73.

29 Schläger - Schäfer 1971, 560; Blackman 1973, 361; Schäfer et al. 1981, 59; Hellenkemper - Hild 2004, 317. 
tedir. Kuzey Demirleme Alanı'na giren büyük teknelerin İç Liman bölgesine ulaşabilmeleri için bu alanda sualtında yer alan vadi benzeri daha derin bir alanı takip ederek "S" biçiminde bir rota ile günümüzde i̇ç Limanı Kuzey Demirleme Alanı'na bağlayan kanala ulaşmaları gerekmektedir. Alanın bu mevcut durumu doğal bir korumanın yanında kılavuz olmadan İç Liman'a girişin büyük boy gemiler için tehlikeli bir durum yaratacak potansiyelde olduğunu da ortaya koymaktadır. Kuzey Demirleme Alanı́nın güney bölümünde yer alan erken dönem kent surunun ${ }^{30}$ bir bölümü olan kıyı duvarı sahil şeridini takip ederek Kuzey Demirleme Alanı ile İ̧̧ Liman alanının birleştiği noktada 90 derecelik dönüşler ile yaklaşık $8 \mathrm{~m}$. uzunluğunda iki basamak oluşturmakta ve iç limana doğru dönmektedir. Günümüzde üzeri otopark olarak kullanılan alanın dolgusu nedeniyle nereye bağlandığı tam anlaşılamaya bu duvar yapısı, İç Liman alanının güney kıyısını takip eden duvar yapısı ile birleşerek hem kent surunu tamamlıyor hem de İç Liman'a giriş oluşturarak belki de bu limanın girişinin zincirle kapatılabilmesine olanak sağlıyor olmalıydı.

Kentin kuzeyindeki demirleme alanının batı ve kuzey bölümü günümüzde kentin gerisindeki Tahtalı Dağı'dan sahile akan yağmur suları ve seller aracılığıyla buraya taşındığı düşünülen çakılla kaplanmış olan bir kumsaldır. Kıyı hattında dalgaların aşındırması sonucu açığa çıkmış olan çok sayıda ve tipte mezar yapısı görülmektedir. Bu alan nekropolis alanı olarak kullanılmıştır ve söz konusu bölgede geç dönemde devşirme malzemelerle yapılmış kıyı yapıları bulunmaktadır. Kıyıya yakın bu alanda ve sualtında da kıyıdaki yapılardan ve nekropolis'ten geldiği anlaşılan çok sayıda mimari yapı elemanı, sütun tamburu ve sağlam durumda büyük boy bir lahit ${ }^{31}$ ile kapağı bulunmaktadır (Fig. 4). Dalgakıran yapısının doğusunda ise 5-6 metre derinlikte az sayıda amphora ve seramik kap parçaları bulunmaktadır. Alanın geneline bakıldığında su seviyesinin oldukça sığ olması bu alanda olası batıklara ait malzemelerin dalgalar ile kıyıya ya da daha derine çekilmiş olması intimalini güçlendirmektedir. Öte yandan gerek antikçağ gerekse günümüz ziyaretçileri tarafından serbest dalışla rahatlıkla ulaşılabilecek derinlikte olması neticesinde günümüze ulaşabilen küçük eser niteliğinde sualtı kültür varlığına rastlanılmasını oldukça güç-

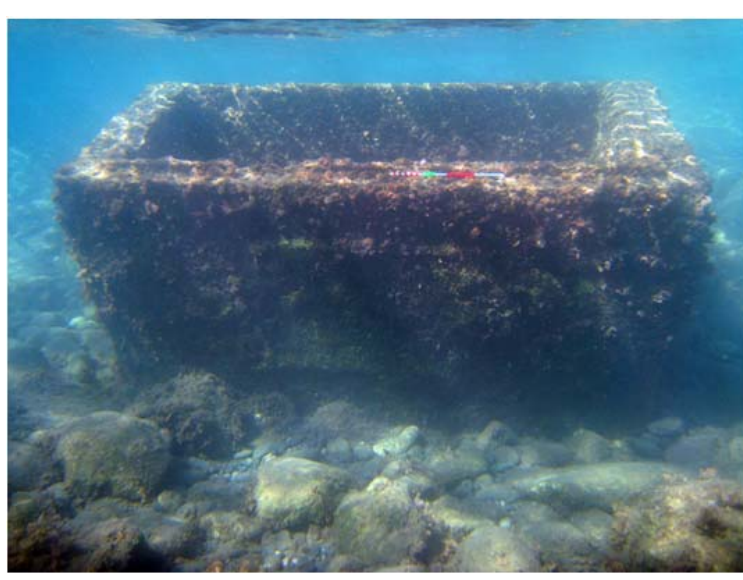

Fig. 4. Kuzey Demirleme Alanı Lahit Teknesi leştirmektedir.

Diğer yandan bölgenin rüzgâr aldığı yönler ve bu rüzgârların dönemlerine bakıldığında demirleme alanının denize açılan güney batı yönünden neredeyse yıl boyu doğrudan rüzgâr aldığı görülmektedir (Fig. 1). Söz konusu demirleme alanını sınırlayan kuzeybatı-güneydoğu doğrultulu dalgakıranın, büyük oranda yaz aylarında bölgede hâkim olan ve yaklaşık 1 m. yüksekliğinde dalga oluşturan doğu rüzgârları için inşa edildiği ve gemileri bu dalgalardan korumak amacıyla yapıldığı açıktır. Ancak rüzgârın estiği yöne göre kimi zaman dalgakı-

30 Güney Liman Alanı'nda, Kuzey Yerleşim'de ve Kent Akropolis'inde dörtgen izodomik duvar olarak adlandırılan erken dönem kent surunun benzer duvarları bulunmaktadır ve M.Ö. V.- II. yüzyıllar arasına tarihlendirilmektedir (Schäfer 1981, 54, 62, 66).

31 Bu lahit olasılıkla Beaufort'un 1881 yılında burayı ziyareti sırasında gördüğü iki lahitten biri olmalıdır. Mermerden üretilmiş bu lahitlerden birinin üzerinde alçak kabartmalı uzanmış insan figürü ile yan yüzünde çiçek ve meyve çelengi, diğerinde cenaze alayı ve yaban domuzu, gergedan, fil figürleri olduğu ifade edilmektedir (Beaufort 2002, 62). 
ranın güney bölümü kimi zamanda kuzey bölümü kullanılmış olmalıdır. Dolayısıyla Kuzey Demirleme Alanı olarak tanımlanan alanın sadece dalgakıranın güney bölümü ile sınırlandırılamayacağı kuzey bölümünün de aynı işlevde olabileceği düşünülmektedir.

İç Liman Alanı (?)

Phaselis iç Limanı olarak adlandırdığımız alan, Kent Akropolis'inin kuzeybatısında, kuzey demirleme alanınınsa batısında konumlanmaktadır. Bu alan yaklaşık 500×130 metre ölçülerinde, doğu batı uzantılı ve günümüzde de bir kanalla kuzey demirleme alanına bağlantısı olan bir bataklık alanıdır (Fig. 1). Strabon, Phaselis limanlarından bahsederken üç limanı ve bir bataklığı olduğunu aktarmaktadır ${ }^{32}$. Ancak günümüzde de bataklık durumundaki alanın güney bölümünde, bataklık alanın kıyısını takip eden yaklaşık $1 \mathrm{~m}$. genişliğinde ve $350 \mathrm{~m}$. uzunluğunda bir duvar ve duvarın gerisinde cadde ile depolama alanı olabilecek mimaride yapılar bulunmaktadır. Ayrıca bataklık alanının kuzeyinde cephesi bataklık alana bakan hâkim konumda tapınak olduğu önerilen büyük bir yapı ile bataklık alanının batısında antik döneme ait bir cadde bulunmaktadır ${ }^{33}$. Yapının atkıı izodomik düzgün iş̧̧ilikli duvar yapısı burasının Geç Klasik - Erken Hellenistik Dönem'e ait büyük boy bir kamu yapısı olduğunu düşündürmektedir ve bize göre bu yapının konumu erken dönemde bu alanda bulunan bir limana göre seçilmiş olmalıdır. Günümüzde bataklığa dönüşmüş olan bu doğal koy, Ephesos, Miletos, Herakleia, Kaunos, Andriake ve Patara limanlarına benzer özellikte korunaklı bir liman alanıdır. Kuşkusuz kentin güneyinde bulunan Barsak Çayı'nın taşıdığı alüvyon ile güneyden, kentin gerisindeki dağlardan ve vadilerden taşınan alüvyonla ise doğudan kuşatılmış olan iç Liman havzası antikçağdan günümüzde kadar kendine özgü bir habitat oluşturarak bataklığa dönüşmüş, liman olarak kullanıldığı avantajlı durumu sayılan diğer limanlarda da olduğu gibi geç dönemde alüvyonla dolarak işlevini yitirmesine neden olmuştur. Bu alanda kazı ya da sondaj yapılmadığı için havzası ve liman yapıları henüz tam olarak bilinmemektedir. M.Ö. I. yüzyıl ile M.S. I. yüzyıl arasına tarihlendirilen Merkezi Liman ${ }^{34}$ (Kent Limanı) olasılıkla günümüzde halen bataklık durumunda olan erken dönem liman alanı olduğunu düşündüğümüz alanın kullanılamaz hale gelmesinden sonra inşa edilmiş olmalıdır. Bu alandaki gözleme dayalı bulguların ileriki yıllarda bu alanda yapılacak jeofizik araştırmaları ve kazı çalışmaları sonucunda daha net bilgilere dönüşeceği kuşkusuzdur.

\section{Merkezi Liman (Kent Limanı)}

Merkezi Liman, güneyde Kentin Akropolis'inin bulunduğu yarım ada, kuzeyde kent surunun da bulunduğu, kuzey demirleme alanını Merkezi Liman'dan ayıran küçük bir yarım ada ve batıda kentin ana caddesinin aksında yer alan küçük bir kumsalla sınırlanan doğal bir koyda bulunmaktadır (Fig. 1). Liman alanı yaklaşık $7500 \mathrm{~m}^{2}$ lik bir havzaya sahiptir ve girişi doğu yöndedir. Limanın mendirekleri aynı zamanda kent surunun da uzantısıdır ve bu limanın bir [limen kleistos] kapalı liman olduğunu göstermektedir ${ }^{35}$ (Fig. 5-6). Kuzey mendireğinin giriş açıklığındaki ucundan $35 \mathrm{~m}$. kuzeyde söz konusu alanda kule bulunduğuna işaret eden mimari bir düzenleme görülmektedir. Bu kulenin hem mendireğin dalgalara mukavemet göstermesi amacıyla güçlendirme işlevine sahip hem de limanın savunma sistemi için işlevsel olarak kullanılabilen bir kule olduğu düşünülmektedir. Temel seviyesinde günümüze ulaşmış olan bu kule-

32 Strab. XIV. 3. 9.

33 Schäfer et al. 1981, 186, taf. 4, Q1.

34 Blackman 1973, 359.

35 Knoblauch 1969, 104-116; 1972, 50-85; Blackman 1973, 360; 1982, 371; 2008, 654. 


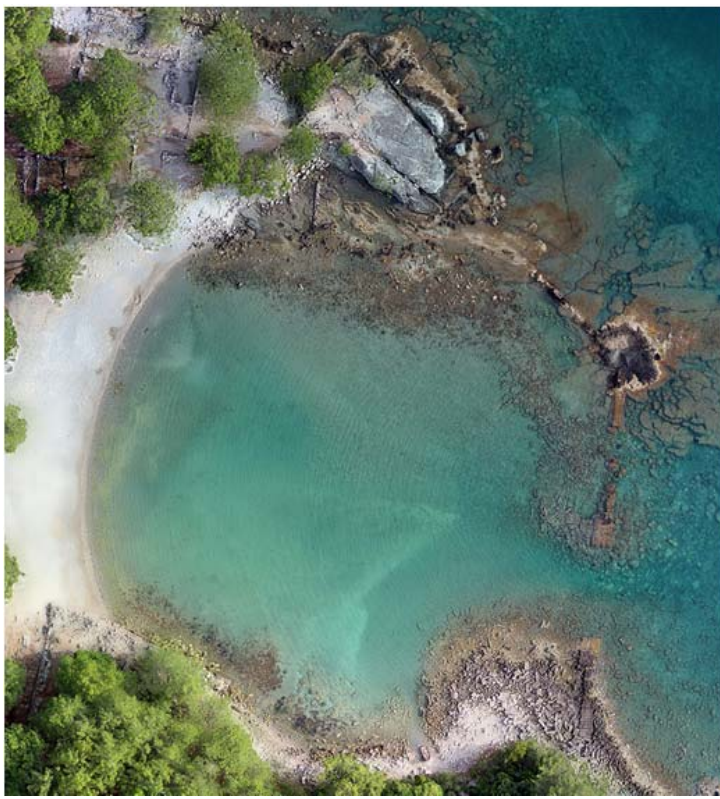

Fig. 5. Merkezi Liman (Kent Limanı) Hava Fotoğrafı

(A. Karahan)

nin yapımında, antikçağ limanlarında sıkça karşılaşılan hidrolik beton kullanıldığını ${ }^{36}$ gösteren harç kalıntıları görülmektedir. Bütünlüğünü büyük oranda koruyamamış mendireğin sualtında kalan bölümünde açıklıklar görülmektedir. Söz konusu açıklıklar mendireğin inşası sırasında liman havzasındaki kirliliğin deşarjı amacıyla yapıımış bir açıkık gibi görünmesine karşın bu açıklığın tuzlu suyun ve dalgaların etkisine maruz kalarak dağımış konglomera blokların bıraktığı boşluk olma intimalide bulunmaktadır. Kent Limanı içindeki alanda gerek liman yapılarına gerekse mendirek yapısına ait çok sayıda blok bulunmaktadır. Çeşitli tip ve boyuttaki bloklar arasında delikli ve silmeli bloklar bulunduğu görülmekte, ancak blokların yüzeyleri yosun ve kekamoz ile kaplı olması nedeniyle işlevleri tam olarak anlaşılamamaktadır.

Mendireğin günümüze ulaşan kısmından onun yapım tekniği ve duvar örgü tekniği anlaşılabilmektedir. Mendireğin etrafında, sualtında yine mendireğin üst bölümlerine ait olduğu anlaşılan çok sayıda blok bulunmaktadır (Fig. 5, 9). Merkezi Liman yaklaşık 95 m. genişliğindeki ve 98 m. uzunluğundaki neredeyse yuvarlak bir yapıya sahiptir. Genel formuna bakıldığında; üç tarafı (kuzey, güney, batı) kara ile çevrili olan liman alanı bu sayede korunaklı bir hal almaktadır. Denize açılan doğu yönüne gerek doğal etkenler gerekse güvenlik faktörü dikkate alınarak ve limanın doğusunda bulunan kayalık alanında da etkin kullanımı ile bir mendirek inşa edilmiştir. Kuzey yönünde kesme taş blokların kullanımı ile inşa edilen 1,70 m. genişliğindeki mendirek, karadan 15,75 m. güneydoğu yönünde uzanmaktadır. Uzandığı noktada bulunan kayalık alanın kuzeybatı kısmıyla birleşen duvar, diğer köşesinden 29×3,85 m. ölçülerinde güneye doğru devam etmektedir. Bir kısmı halen sualtında bulunan mendireğin güney ucu $0,15 \mathrm{~m}$. kotta olup, çevresinde $-0,20 \mathrm{~m}$. ile 2,90 m. arasında değişen derinliklerdeki mendireğe ait dörtgen bloklar yaklaşık $37 \mathrm{~m}^{2}$ alana dağılmış halde bulunmaktadır. Güneyde ise kuzeyden uzanan mendireğin aksına gelecek şekilde yaklaşık $35 \times 2 \mathrm{~m}$. ölçülerinde ve kuzeye doğru uzanan bir mendirek inşa edilmiştir. Limanı çevreleyen her iki mendire-

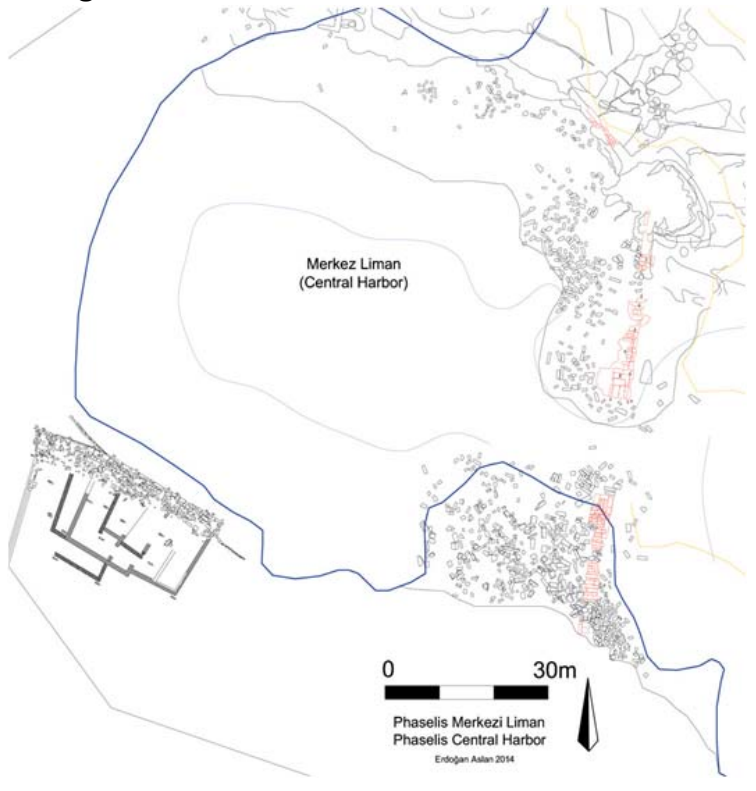

Fig. 6. Merkezi Liman (Kent Limanı) Planı 


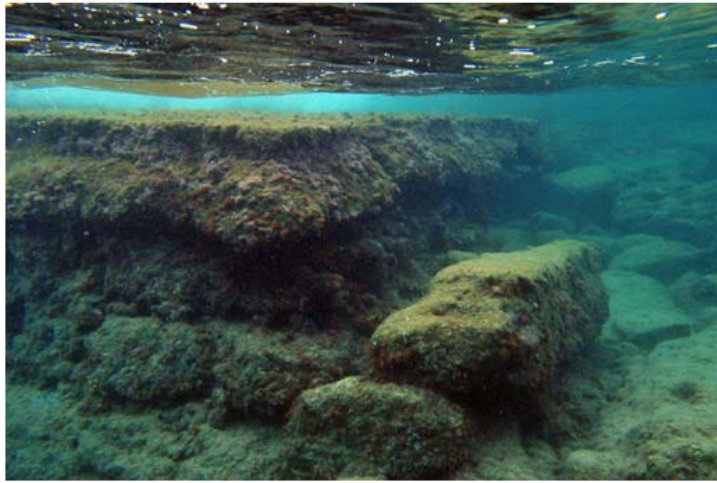

Fig. 7. Merkezi Liman Mendireği Sualtı Görünümü

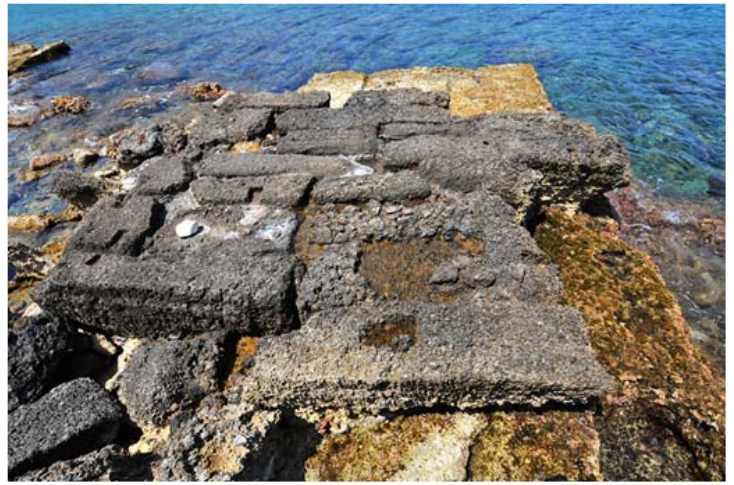

Fig. 8. Merkezi Liman in-situ Bloklar ve Kene Yuvaları

ğin su altında kalan uç kısımları, mendireğin gövdesinden daha geniş tutularak $(2,80 \times 3,70 \mathrm{~m}$.) bu alana benzer liman örneklerinde olduğu gibi ${ }^{37}$ karşııklı kuleler inşa edildiği düşünülmektedir. Merkezi Liman güney mendireğinin sualtında -1,55 m. kottan başlayarak (Fig. 7) mendireğin ana kara ile birleştiği alanda in situ olarak korunmuş duvar sırasından 4,09 m. kota kadar yükseldiği anlaşılmaktadır. Ancak günümüze ulaşan kısmın büyük bir bölümü $0,55 \mathrm{~m}$. kottaki duvar ve altındaki diğer duvar sıralarıdır. Yaklaşık 35×30 metrelik bir alana dağılmıs halde bulunan mendireğin üst duvar sıralarına ait olduğu anlaşılan bloklar, yoğunlukla mendireğin batı kısmında bulunmaktadır ve kent surunda görülen bosajlı bloklara benzer niteliktedir (Fig. 9-10). Doğudaki açık denizden gelen rüzgâr ve dalganın etkisiyle bu blokların genel itibariyle mendireğin batı kısmına doğru yıkıldığı anlaşılmaktadır. Güney ve kuzeyden aynı aks üzerinde birbirine uzanan mendirekler arasında limana giriş için yaklaşık 17,45 m. genişliğinde bir açıklık bırakılmıştır.

Merkezi Limanın güney mendireğine ait duvarın $0.55 \mathrm{~m}$. kotundaki in situ kısmı yaklaşık 2×1×0,60 metre boyutlarındaki bloklarla izodomik duvar örgü tekniği kullanılarak örüldüğü anlaşılmaktadır. Daha üst sıraya gelen blokların her sırada ölçülerinin değiştiği görülmekte, ancak duvar örgüsünün bir sıra dikey bir sıra yatay olarak yerleştirildiği ve her bir blok sırası için alt sıradaki bloklar üzerine blok yatakları işlendiği görülmektedir. Bu blok yataklarının amacı açık denizden gelen dalgalara mukavemet göstermesi amacıyla blokların birbirine daha organik bağ oluşturmasıdır. Mendireğin uç kısmında ise hem kule bulunması hem de üç tarafının açık olması nedeniyle blokların birbirine bağlanması için blok yatağı yerine kenetler kullanıldığı görülmektedir. Bu alanda bulunan 0,00 kotundaki ve 0,55 kotundaki in situ bloklar üzerindeki kırlangıç kuyruğu (çift kelebek kanadı) kenet yuvalarının uzunlukları 0,32 m., en geniş uç kısımları 0,10 m., en dar bel kısımları 0,06 m. ve derinlikleri ise 0,06 metredir (Fig. 8, 11). Bu alanda in situ durumda bulunan kenet yuvaları antikçağ liman mimarisinde bilinen bir uygulama olmasına karşın limanla

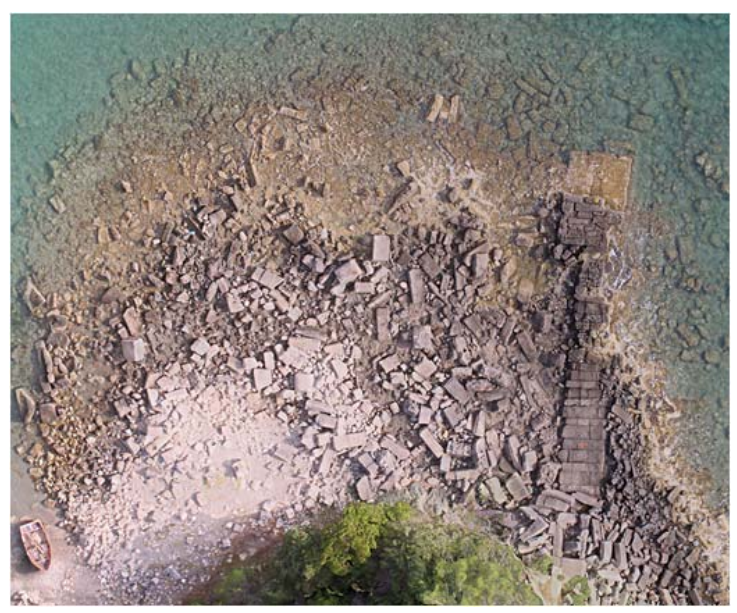

Fig. 9. Merkezi Liman Güney Mendireği Alanı Genel Görünüş

37 Knoblauch 1969, 104-116; 1972, 50-85; Blackman 1973, 360; 1982, 371; 2008, 654; Bjorn 2011, 15 vd. 


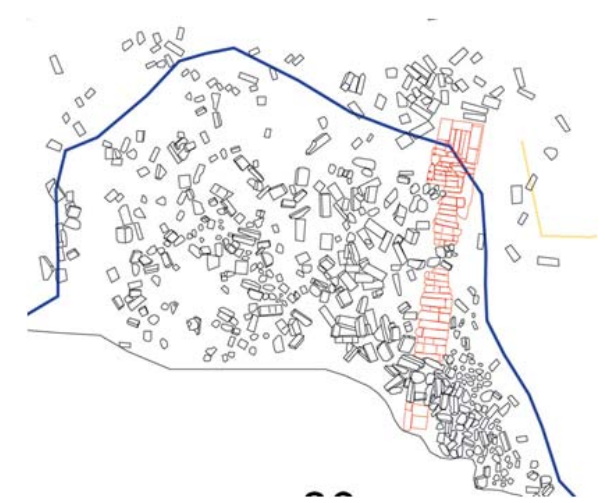

Fig. 10. Merkezi Liman Güney Mendireği Rölöve

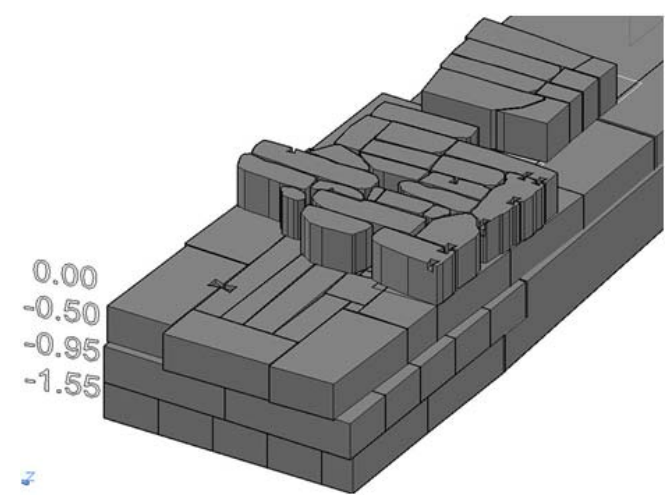

Fig.11. Merkezi Liman Güney Mendireği in-situ Bloklar

rın tarihlendirilmesi noktasında ek bir veri sunmamaktadır ${ }^{38}$.

Merkezi Liman havzası içindeki kuzey bölümde temel seviyesinde bazı yapı kalıntıları görülmektedir, bu kalıntılar olasılıkla limana ait yapılardandır ancak işlevlerinin ne olduğu tam olarak anlaşılamamaktadır. Liman havzasının güney bölümünde, kentin ana caddesinin kuzey ucunu dik kesen bir duvar yapısı ve gerisinde bir yapı topluluğu bulunmaktadır. Söz konusu duvar deniz seviyesinden $1 \mathrm{~m}$. yüksektedir ve geriye doğru basamak yaparak kademeli olarak yükselmektedir. Merkezi Liman'ın güney batısında yer alan liman duvarı konglomera bloklardan oluşmaktadır. Günümüze ulaşmış durumu ile duvarın ölçüleri 39x5 metredir. Kullanılan bloklar yaklaşık 1,50 ila $2 \mathrm{~m}$. uzunluğunda ve 0,30 ila 0,60 m. genişliğindedir. Duvarın güneydoğu cep-

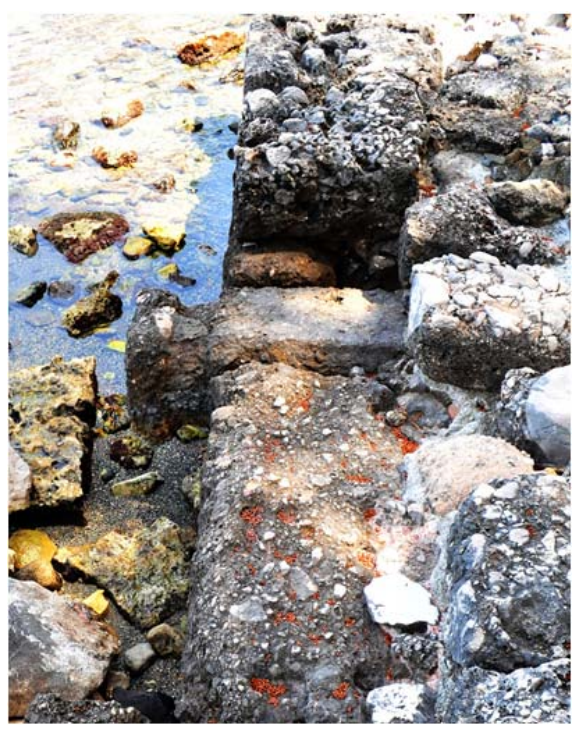

Fig. 12. Merkezi Liman Palamar Bloğu hesi $0,70-1,00 \mathrm{~m}$. yüksekliğindedir ve $2,80 \mathrm{~m}$. yüksekliğe kadar kuzeybatıya doğru düzensiz olarak yükselmektedir. Duvarı oluşturan blokların arası irili ufaklı moloz taşlar ve harç ile doldurularak desteklenmiştir. Limanın güneybatı kısmında $+2,00 \mathrm{~m}$. yükseklikten başlayarak 4,50 m. yüksekliğe ulaşan farklı ölçülerde, iç içe geçmiş odaların oluşturduğu mekânlar bulunmaktadır. Bu mekânlara ait duvarların kalınlığı 0,70 metredir ve kapladığı alansa yaklaşık 27,5×15,5 metredir (Fig. 6).

Doğu-batı doğrultulu duvar üzerinde in situ olarak korunmuş toplam 6 adet palamar bağlama babası bulunmaktadır. Bazıları birbirine 3 metre bazıları ise 6 metre aralıklarla dizilmiş olan in situ durumdaki mantar biçimli (bollard) bağlama babalarının ölçüleri 0,60×0,40×2 metredir ve denize doğru yatay olarak durması ünik bir özellik$\operatorname{tir}^{39}$ (Fig. 12-13). Antikçağ limanlarında mantar biçimli bağlama babaları görülmekle beraber bunlar dikey konum-

38 Aslan 2014, 139, dn. 41.

39 Genel terminolojide moorig stone (halka biçimli bağlama yeri) ve bollard (iskele babası biçiminde bağlama yeri) denen ve gemilerin iskeleye yanaştıktan sonra halatlarını bağladıkları taş ya da metal düzenlemelerden halka ya da delik biçiminde olanlara 'palamar bağlama halkası'; monolit biçimde mantar ya da sütun şeklinde olanlarysa 'palamar bağlama babası' denilmektedir. Konuya ilişkin olarak ayrıca bk. Testaguzza 1964, 173; Blackman 1973, 355; 1982, 203; Williams 1976, 73; Theodoulou-Memos 2007, 253. 
landırılmaktadırlar. Böylesine yatay konumlandırılan bloklara daha çok bağlama halkası (mooring stone) yapılmaktadı ${ }^{40}$. Her iki palamar bağlama tipinin özelliklerini birlikte taşıması dikkat çekici bir özelliktir. Bunun nedeni büyük olasılıkla iskele üzerindeki kısıtlı alanı daraltmamak adına, iskele duvarına yatay olarak konumlandırıldığı anlaşılan blokta bağlama halkası olması beklenirken, bloğun cinsinin konglomera olması nedeniyle ortasına açılacak halka bloğu zayıflatacağından halka yerine bollard adı verilen mantar biçimli olarak yapılması kaçını Imaz hale gelmiştir. Bağlama babalarının bulunduğu duvar yapısı yaklaşık $40 \mathrm{~m}$. uzunluğundadır ve bu alanın gemilerin bağlandığı rıhtım ve gerisindeki yapıların da rıhtımla ilişkili yapılar olduğunu göstermektedir. Rıhtım duvarının batı bölümünde 0,40x0,60 m. ölçülerinde bir kanal görülmektedir. Bu kanalın daha önceki yıllarda C. Bayburtluoğlu tarafından yapılan kazılar sırasında Sütunlu Cadde üzerinde

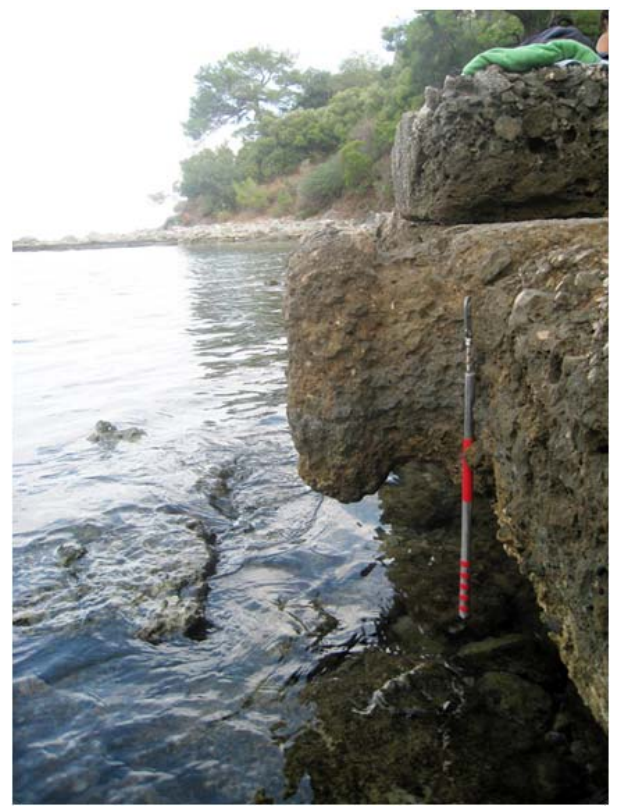

Fig. 13. Merkezi Liman Palamar Bloğu bulunan Latrina yapısının kanalizasyon tesisi olarak inşa edilerek limana uzatılan ve liman içine doğru tahliye edilen atık su kanalının ağzı olduğu anlaşılmaktadır ${ }^{41}$. İskele işlevi gören bu alanın gerisinde depo ya da dükkân benzeri mimari yapıların bulunması bu alanın rıhtıma yanaşan gemilerin kargolarını boşalttıkları ve Phaselis'ten ihraç edilecek malların gemilere yüklendiği işlevsel bir ticaret alanı olduğuna işaret etmektedir. Benzer limanlarda da bu alanda dükkânlar, depolar, gümrük binaları ve sarnıçlar gibi mimari yapılar bulunmaktadır².

\section{Güney Limanı}

Güney Limanı Kent Akropolis'inin yer aldığı yarım adanın batı kısmında bulunmaktadır. Limanın batısındaki yüksek tepeler bölgede hâkim olan batı rüzgârlarını kesen bir konumdadır ve limanı oldukça korunaklı bir alan haline getirmektedir. Özellikle kış aylarında güneyden esen şiddetli rüzgârlara yönelik olaraksa kentin batı bölümündeki ana karadan başlayarak denizin doldurulması ile doğu-batı uzantılı, yaklaşık $100 \mathrm{~m}$. uzunluğunda ve $50 \mathrm{~m}$. genişliğinde yapay bir mendirek inşa edilmiştir (Fig. 1). Kıyı alanında yaklaşık $50 \mathrm{~m}$. uzunluğundaki bölümü günümüzde su üzerinde görülebilirken diğer bölümünün tamamı $1 \mathrm{~m}$. ile $6 \mathrm{~m}$. arasındaki bir derinlikte sualtındadır. Mendireğin inşasında sualtında kalan bölüm akropolis'in bulunduğu kayalık alandan kesildiği anlaşılan değişik boyutlardaki moloz ile doldurularak bir gövde oluşturulmuştur (Fig. 16). Büyük bir bölümü günümüzde sualtında bulunan dalgakıranın kıyıya yakın olan su üzerindeki bölümde ise, bu gövdenin üzerine kesme taş konglomera bloklarla inşa edildiği anlaşılan, $45 \mathrm{~m}$. uzunluğunda ve kuzeydoğu-güneybatı doğrultulu bir duvar ile çeşitli dörtgen mekânlar bulunmaktadır. Ancak bu blokların büyük bir bölümü tuzlu su ve dalgaların aşındırıcı etkisi ile blok görünümünü kaybetmiş ve yine dalgaların yıkıcı etkisi ile dağılmış olması nedeniyle söz konu-

40

Mengarelli 1900, 637-638 fig. 2; Gerkan 1959, 142 fig. 1; Testaguzza 1970, 171; Shaw 1972 fig. 21; Williams 1976, 75 fig. 3; Blackman 1982 fig. 2; Casson 2002, 121; Hadjidaki - Stefanakis 2004, 118; Teodoulou Memos 2007, 257 fig. 4; Aslan 2011, 48 lev. 26. 2; Doksanaltı - Aslan 2013, 234 fig.7.

41 Bayburtluoğlu 1983, 183 vd.

42 Shaw 1972, 91; Blackman 1982, 204; 2008, 653; Casson 2002, 143. 


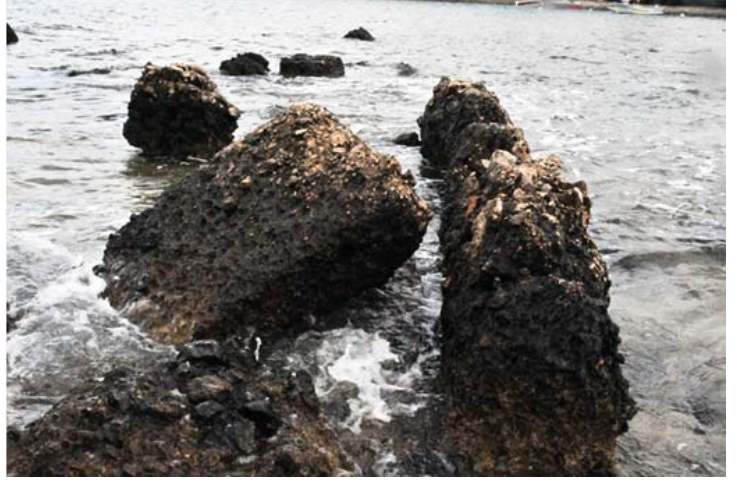

Fig. 14. Güney Limanı Bloklar

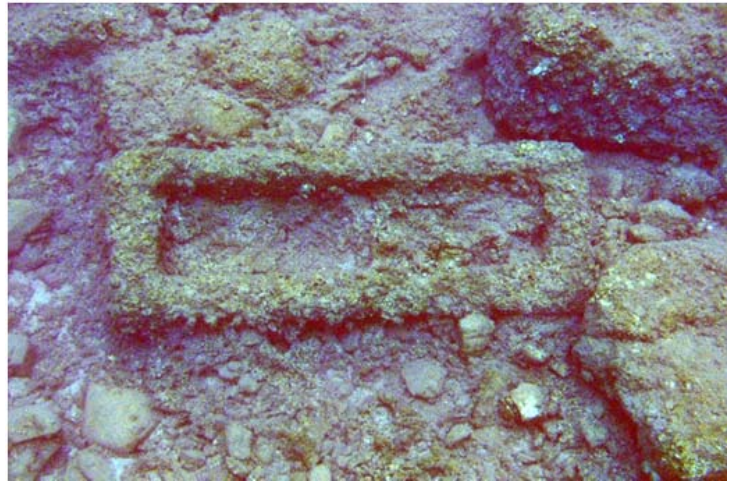

Fig. 15. Güney Limanı Lahit

su mekânların işlevi anlaşılamamaktadır (Fig. 14). Güney Limanı mendireğinin denize doğru olan uç kısmında su derinliği yaklaşık 12 metredir ve bu alan doldurularak mendirek gövdesi tamamen yapay olarak inşa edilmiştir. Mendireğin kıyıya yakın bölümlerinde sualtında 0,40 m. derinde doğu batı uzantılı duvar sıraları günümüzde halen görülebilmektedir (Fig. 17). Bu duvarlar olasılıkla mendireğin antikçağda su üzerinde kalan bölümleridir. Büyük bölümü sualtında bulunan mendireğin üzerinde yaklaşık $5 \mathrm{~m}$. derinlikte bir adet lahit teknesi bulunmaktadır (Fig. 15). Bu lahdin bu alanda batan bir geminin kargosuna mı ait olduğu, yoksa sonraki çağlarda mendireğin tekrar onarımına ilişkin bir mimari eleman olarak mı kullanıldığı bilinmemektedir. Güney Limanı́nın havzasının kuzey ve batı bölümü günümüzde ince kumlu bir sahil şerididir ve sahil bandında bulunan geç döneme ait, temel seviyesinde de korunmuş bir duvar dışında herhangi bir kalıntı görülmemektedir. Liman havzasının doğu bölümünde kentin ana caddesinin batı ucu ve çok sayıda yapı kalıntısı bulunmaktadır. Aynı alanda günümüz teknelerinin yanaştığı ahşap bir iskele ve kent suruna ilişkin akropolis'in eteklerini dolaşan duvar kalıntıları görülmektedir. Gemilerin yanaştığı rıhtım yapılarının olması beklenen bu alan, akropolis'in yamacından gelen akıntı toprak nedeniyle yoğun bir dolgu ve sık bitki örtüsü ile kaplanmıştır ve kıyıda limana ilişkin herhangi bir yapı olup olmadığı yüzeyden gözlemlenememektedir. Günümüzde yüzeyden görülebilen ve gerek sualtında gerekse de kıyı alanlarında in situ olarak korunan duvarların örgü biçimi ve kent akropolis'ini çevreleyen erken dönem surları ile organik bağı olması bakımından burasının Phaselis'in erken dönem liman alanlarından biri olduğu anlaşılmaktadır ${ }^{43}$. M.S. 131 yılında Roma imparatoru Hadrianus'un kenti ziyareti sırasında Güney Limanı'ndan kente giriş yap-

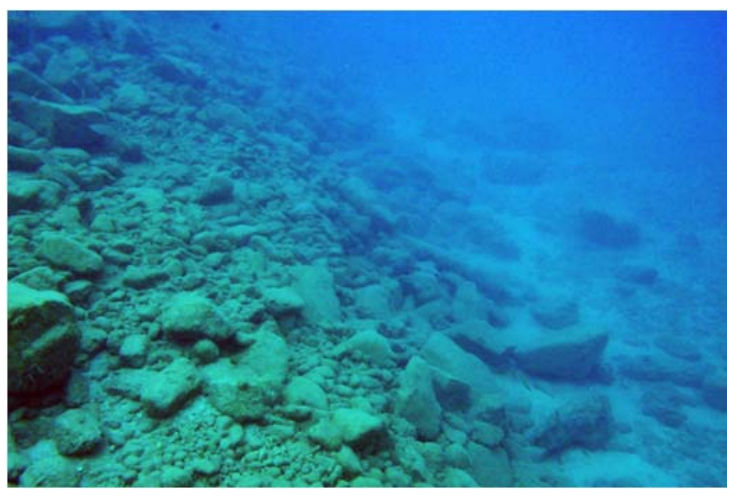

Fig. 16. Güney Limanı Zemin Dolgusu

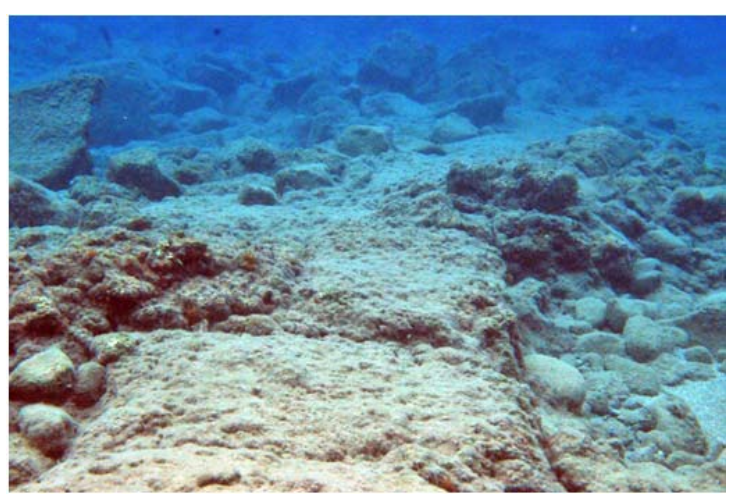

Fig. 17. Güney Limanı Sualtı Bloklar

43

Schäfer et al. 1981, 55 vd. 
ması Phaselis'in -muhtemelen- ilk inşa edilen limanı olan Güney Limanı'nın Roma Dönemi'nde de yoğun olarak kullanıldığının en iyi belgelerinden biri olarak gösterilebilirr ${ }^{44}$. Güney Limanı'nı Phaselis'in diğer liman alanlarından ayıran en büyük fark kentin kuzeyinde yer alan sığ ve deniz yüzeyine yakın kayalıkların ve de liman havzasının çevresinde falez benzeri sarp kayalıkların bulunmamasıdır. Dolayısıyla özellikle ticaret gemilerinin yanaşmasına ve ticaret ürünlerinin yüklenmesi ya da boşaltılmasına olanak sağlamasıdır. Güney Limanı'nın daha çok bu işlevde kullanılması da kentin ticari potansiyelinden yararlanmak isteyen tüccarların ihtiyaçlarına cevap verebilecek ticari yapıların ve kentin liman işletmeleri ile ilgili resmi binaların bu alanda yoğunlaşmasına neden olmuştur ${ }^{45}$.

\section{Değerlendirme}

Phaselis kentinin bu alana kurulmasının nedeni olan ve dış dünya ile bağlantısını sağlayan kent limanları, kuşkusuz kentin tarihi ve önemi için araştırılması gereken en önemli alanlarından biridir. Phaselis'in antikçağ liman kentleri arasında ender olarak görülen üç limanı ${ }^{46}$ ile de liman kentleri arasında ayrı bir öneme sahip olduğu görülmektedir ${ }^{47}$. Boyut ve tipoloji bakımından ihtiyaca ve topografyaya göre çeşitlilik gösteren antikçağ limanlarının ${ }^{48}$ tipolojik açıdan karşıllaştırılmaları mümkün olmamakla birlikte kısmen sınıflandırılabilmektedir ${ }^{49}$. Buna göre Phaselis limanlarından İç Liman, tamamen doğal koyun kullanımı ile yapılmış, diğer limanları ise doğal koya yapay mendirekler inşa edilerek liman alanları oluşturulduğu anlaşılmaktadır. Phaselis limanlarının tarihlendirilmesi konusunda ise eldeki bulgular değerlendirildiğinde ${ }^{50}$ iç Liman ve Güney Liman olasılıkla kentin kuruluşu ile çağdaş bir tarihte, Kuzey Demirleme Alanı ile Merkezi Liman ise Geç Hellenistik Dönem'den itibaren kullanıma girmiş olmalıdır ${ }^{51}$. İşlevlerine yönelik değerlendirildiklerinde ise Güney Limanı'nın çoğunlukla ticari faaliyetler için kullanılmış olduğu anlaşılmaktadır. İç Liman alanıysa henüz tam anlamıyla araştırılamamıştır; ancak bize göre konumu ve korunakı havzası nedeniyle askeri amaçlar ile gemi yapım tersanelerinin konumlandırıldığı bir işleve sahip olmalıdır.

Kuzey Demirleme Alanı uzak yoldan gelen ticaret gemileri tarafından Güney Limanı'na mal indirmeden ya da indirdikten sonra bekleme alanı olarak kullanılmış olmalıdır. Ayrıca bölgedeki rüzgârların estiği yöne göre değişkenlik gösteren demirleme alanında yer alan dalga kıranın güneydoğusu ya da kuzeybatısını kullandıkları bir ara istasyon olmalıdır. Merkezi Liman olarak anılan ve kentin en iyi korunmuş limanının ise, gerek boyutu gerekse de Hellenistik kent suru ile çevrelenmiş olması suretiyle bir kapalı liman [limen kleistos] formuna sahip olması bu limanın büyük ölçüde askeri bir amaç taşıdığına işaret etmektedir. Ancak bu limana ait kıyı yapılarının

44 Tüner-Önen 2008, 313 vd.

45 Schäfer et al. 1981 taf. 39,

46 Bize göre Strabon’un göl olarak tanımladığı günümüz bataklık alanı da kentin erken dönem liman alanlarından biridir ve toplamda dört limanı bulunmaktadır.

47 Knidos, Amastris, Piraieus az sayıdaki üç limanlı kentlerdendir. (Knidos: Gibbons 2006, 30 vd.; Amastris: Lehmann - Hartleben 1923 plan XX; Piraieus: Blackman 1982 fig. 3)

48 Aslan 2014, 138.

49 Aslan 2011, 24 vd.

50 Çalışmanın giriş bölümünde ele alınan antik kaynaklar ve limanlara ait bölümlerde sözü edilen arkeolojik kalıntılar ile değerlendirilmektedir.

51 Tarihlendirme noktasında yukarıda sayılan gerekçelerin yanı sıra, her iki limanın mendireğinde de hidrolik harç kullanıldığı görülmektedir ve sualtı yapılarında hidrolik betonun kullanılmasına ilişkin bilinen en erken örneği (terminus post quem) M.Ö. III. yüzyıla tarihlenen Puteali ve Cosa rıhtımları oluşturmaktadır (bk.: Oleson 1985, 169), dolayısıyla bu tarihten sonraki bir döneme verilmeleri gerekmektedir. 
arasında üretime yönelik yapılar ile depolama alanlarının bulunması Güney Limanı́nın kullanıması için uygun olmayan hava koşullarında bu limanın küçük ölçekli ticari gemilerin girebildiği ticari amaçlı bir liman olarak da kullanıldığını düşündürmektedir. Diğer yandan Merkezi Liman alanının, İç Liman Alanı́nın alüvyon dolgusu ile işlevini yitirmeye başlamasının ardından Hellenistik Dönem'de inşa edildiği düşünülmektedir. Merkezi Liman'a ilişkin diğer bir olgu ise, bu alanda yer alan iskelede bulunan in situ gemi bağlama babalarının yatay konumlandırılmış bollardlardan oluşmasıdır. Bu durum antikçağda ender rastlanan bir niteliğe sahiptir. 


\section{BíBLIYOGRAFYA}

\section{Antik Kaynaklar}

Flor. epit.

Liv.

Plut. Aleks.

Strab.

Thuk.

\section{Modern Literatür}

$A A$

AJA

Arslan 2003a

Arslan 2003b

Arslan - Tüner Önen 2011

Arslan 2012

Aslan 2011

Aslan 2014

Bass 1986

Bayburtluoğlu 1983

Beaufort 2002

Bean 1968

$B J b$

Bjorn 2011

Blackman 1973

Blackman 1982

Blackman 2008
(= Annius Florus, Epitome of Roman History)

Kullanılan Metin ve Çeviri: Lucius Annaeus Florus, The Two Books of the Epitome, Extracted from Titus Livius, of All the Wars of Seven Hundred Years. Trans.: E. S. Forster. London - New York 1929 (The Loeb Classical Library).

(= Livius, Ab Urbe Condita).

Kullanılan Metin ve Çeviri: Livy, From the Founding of the City. Trans.: A. C. Schlesinger. London - New York 1967 (The Loeb Classical Library).

(= Plutarkhos, Bioi Paralleloi, Aleksandros)

Kullanılan Metin ve Çeviri: Plutarch's Lives, vols. I-XI. Ed. \& Trans.: B. Perrin. London - New York 1959 (The Loeb Classical Library).

(= Strabon, Geographika)

Kullanılan Metin ve Çeviri: Strabo, The Geography of Strabo. Trans.: H. L. Jones. London - New York 1961 (The Loeb Classical Library).

(= Thucydides, History of the Peloponnesian War)

Kullanılan Metin ve Çeviri: Thucydides, History of the Peloponnesian War, vols. I-IV. Trans.: C. F. Smith. London 1919-1923 (The Loeb Classical Library).

Archäologischer Anzeiger.

American Journal of Archaeology. New York.

M. Arslan, "M.Ö. 188 Yılından M.Ö. 67 Yılına Kadar Lykia, Pamphylia ve Kilikia Trakheia Sahillerindeki Korsanlık Faaliyetleri: Nedenleri ve Sonuçları". ADALYA VI (2003) 91-118.

M. Arslan, "Piracy on the Southern Coast of Asia Minor and Mithridates Eupator". OLBA VIII (2003) 195-211.

M. Arslan - N. Tüner Önen, "Akdeniz' in Korsan Yuvaları: Kilikia, Pamphylia, Lykia ve Ionia Bölgelerindeki Korykoslar". ADALYA XIV (2011) 189-206.

M. Arslan, "Pseudo-Skylaks: Periplous". MJH II/1 (2012) 239-257.

http://dx.doi.org/10.13114/MJH/20122783

E. Aslan, Kekova Bölgesi Limanları. Yayınlanmamış Doktora Tezi, Selçuk Üniversitesi. Konya 2011.

E. Aslan, "Bithynia Bölgesi Kalpe Limanı (Port of Kalpe in the Bithynian Region)". OLBA XXII (2014) 129-154.

F. G. Bass, "The Bronze Shipwreck at Ulu Burun". AJA 90 (1986) 85-110.

C. Bayburtluoğlu, "1982 Phaselis Kazısı Raporu". KST V (1983) 181-189.

F. Beaufort, Karamanya. Çev.: A. Neyzi - D. Türker. Antalya 2002.

G. E. Bean, Turkey's Southern Shore. London 1968.

Bonner Jahrbücher des Rheinischen Landesmuseums in Bonn und des Vereins von Altertumsfreunden im Rheinlande. Bonn.

L. Bjorn, The Ancient Harbours of the Piraeus. Volume I. 1: The Zea Shipsheds and Slipways - Architecture and Topography. Athens 2011.

D. J. Blackman, "The Harbours of Phaselis". IJNA $2 / 2$ (1973) 355-364.

D. J. Blackman, "Ancient Harbours in the Mediterranean". IJNA 11/3 (1982) 185-221.

D. J. Blackman, "Sea Transport, Part 2: Harbors". Ed. J. P. Oleson, The Oxford 
Casson 2002

Doksanaltı - Aslan 2013

Gerkan 1959

Gibbons 2006

Hellenkemper - Hild 2004

Hadjidaki - Stefanakis 2004

Heipp-Tamer 1993

IJNA

Knoblauch 1969

Knoblauch 1972

Lehmann-Hartleben 1923

Mengarelli 1900

Müller 2010

Oleson 1985

Schäfer et al. 1981

Schläger - Schäfer 1971

Shaw 1972

Seyrig 1963

Stark 1956

Robert 1966

Testaguzza 1964

Testaguzza 1970

Teodoulou - Memos 2007

Tüner-Önen 2008
Handbook Engineering and Technology in The Classical World. Oxford (2008) 638-670.

L. Casson, Antik Çağda Denizcilik ve Gemiler. Çev.: G. Ergin. İstanbul 2002. E. M. Doksanaltı - E. Aslan, "Karadeniz' de Antik Bir Ada Yerleşimi: AretiasKhalkeritis Adası". Ed. B. Söğüt, Stratonikeia'dan Lagina'ya - Ahmet Adil Tırpan Armağanı - From Stratonikeia to Lagina - Festschrift in Honour of Ahmet Adil Tirpan. İstanbul (2013) 219-240.

A. von Gerkan, Von Antike Architektur und Topographie: Gesammelte Aufsätze. Ed. E. Boehringer, Stuttgart 1959.

M. Gibbons - M. Gibbons, "The Discoveries of Lord Charlemont". Archaeology Ireland 20/2 (2006) 30-35.

H. Hellenkemper - F. Hild, Tabula Imperii Byzantini 8: Pamphylien und Lykien. Wien 2004.

E. Hadjidaki - M. Stefanakis, "Secrets of Phalasarna. Critiko Panorama". Minoa Editions (2004) 101-135.

C. Heipp-Tamer, Die Münzprägung der Lykischen Stadt Phaselis in Griechischer Zeit. Saarbrücken 1993.

The International Journal of Nautical Archaeology and Underwater Exploration. Portsmouth.

P. Knoblauch, "Neuere Untersuchungen an den Häfen von Ägina”. BJb 169 (1969) 104-116.

P. Knoblauch, "Die Hafenanlagen der Stadt Ägina". Adelt 27A (1972) 5085

K. Lehmann-Hartleben, Die Antiken Hafenanlagen des Mittelmeer. Aalen 1963.

R. Mengarelli, "Terracina. Pietro di ormeggio, scolpita, rinvenuta presso il molo dell'antico porto". Notizie degli Scavi di Antichita (1900) 635-638.

K. Müller, "Anonymi Stadiasmus Maris Magni". Ed. K. Müller, Geographi Graeci Minores. Cambridge (2010) 427-514.

J. P. Oleson, "Herod and Vitruvius Preliminarj, Thoughts on Harbour Engineering at Sebastos, The Harbour of Caeseria Maritime". Ed. A. Raban, Harbour Archaeology (1985)165-172.

J. Schäfer, H. Schläger, D. J. Blackman, H. Bremer, J. Christern - P. Knoblauch, Phaselis: Beiträge zur Topographie und Geschichte der Stadt und ihrer Häfen. Tübingen 1981.

H. Schläger - J. Schäfer, "Phaselis zur Topographie der Stadt und des Hafengebietes". AA 86 (1971) 542-561.

W. J. Shaw, "Greek and Roman Harbours Works". Ed. G. F. Bass, A History of Seafaring Based on Underwater Archaeology. London (1972) 87-102. H. Seyrig, "Monnaies Hellénistiques". Revue Numismatique VIII (1963) 764.

F. Stark, The Lycian Shore. London 1956.

L. Robert, Monnaies Antiques en Troade. Volume 1. Paris 1966.

O. Testaguzza, "The Port of Rome" Archaeology 17/3 (1964) 173-179.

O. Testaguzza, Portus: Illustrazione dei Porti di Claudio e Traiano e della città di Porto a Fiumicino. Roma 1970.

T. Theodoulou - C. Memos, "A Voyage to Ancient Greek Harbours on Board Limenoscope". Water Science \& Technology: Water Supply 7/1 (2007) 253-260.

N. Tüner-Önen, Phaselis Antik Kenti ve Teritoryumu. Yayınlanmamış Dok- 
Williams 1976

Yağcı 2011 tora Tezi, Akdeniz Üniversitesi. Antalya 2008.

P. F. C. Williams, "Roman Harbours". IJNA 5/1 (1976) 73-79.

R. Yağcı, "Mersin'in Antik Dönem Ticaret Tarihinde Soli Pompeipolis Limanı". Ed. F. Demir, Türk Deniz Ticareti Tarihi Sempozyumu III. Mersin (2011) 5664. 